became more and more prominent". He concluded: "We should not delude ourselves: in the final analysis, the problem can only be solved through the abolition of nuclear weapons. So long as they continue to exist, the danger will be with us."

Rotblat would certainly have agreed, and Visionary for Peace has a useful appendix of a set of his writings, which include his 2003 paper, 'The Nuclear Issue: Pugwash and the Bush Policies. This contains a typically incisive condemnation of the recent lurch to yet more reliance on nuclear weapons in the Western world: "The use of nuclear weapons is seen by the great majority of people in the world as immoral, due to their indiscriminate nature and unprecedented power. Their possession - and therefore likely use - is thus equally unacceptable, whether by 'rogue' or benevolent regimes." Little wonder then that Pugwash scientists have argued against the replacement of Trident by the United Kingdom.
Few of us are able to achieve a mature balance between our many activities and diverse relationships. Yet, despite his hectic work schedule, Joseph Rotblat was universally regarded as an exceptionally kind and generous person. His wife and her mother died in the Holocaust but members of the family joined him in England after the war. An essay by his niece, Halina Sand, demonstrates his humanity so well: "His warmth and kindness to me continued throughout his life, descending through the generations to my two daughters and their children. In his mid-nineties, and in poor health, he was still able to charm his small great-great-niece and twin great-greatnephews, just as he had once enthralled their mother and their grandmother." Joseph Rotblat was indeed a man of peace.

Malcolm Dando is professor of international security at the Department of Peace Studies, University of Bradford, Bradford, West Yorkshire, BD7 1DP, UK.

\title{
Too much information
}

\section{Glut: Mastering Information Through the Ages \\ by Alex Wright \\ Joseph Henry Press: 2007. 296 pp. Ł16.99, $\$ 27.95$}

\section{Ann Blair}

'Information overload' is a phenomenon we know well - a Google search on the term retrieves close to 2 million hits. But is it really as new as we think? "We are not the first generation - nor even the first species - to wrestle with the problem of information overload," Alex Wright reminds us in his ambitious new book, Glut. He seeks a balanced and historically informed assessment of the digital revolution's impact. As a former librarian now working as an information architect, Wright combines insights from his areas of expertise with a wide range of historical and scientific literature aimed at non-specialist audiences. He does not attempt a synthesis of specialist debate, but offers a well-informed account of information management across a surprising range of examples.

Information management systems, which typically rely on a combination of self-organizing networks and hierarchical relationships, are central to biological phenomena - from the evolution of multicellular organisms to the dynamics of social insects. Wright draws from sociobiology the suggestion that evolution has favoured the development of particular human cognitive behaviours in managing information, such as the drive to classify and the emotional attachment to symbols. He turns for confirmation to anthropologist Donald Brown's notion of human universals and notes the particular importance of the ice age that began some 40,000 years ago in forcing humans to interact more closely, thus stimulating the development of drawing and symbolic objects. Wright argues that this "ice age information explosion brought humanity to the brink of literacy".
The book's central chapters follow a more conventional selection of examples spanning the development of Western civilization: from the origins of writing in Mesopotamia for keeping commerce and administration records, to the accumulation of books and bibliographic records (at Alexandria, for example), through the Dark Ages in which Irish scribes worked alone outside traditional hierarchies (like today's bloggers, Wright suggests), and into the age of print in the Renaissance.

The author discusses some high points of early modern information management. For example, Giulio Camillo's memory theatre (around 1550) promised access to all knowledge through a system of visual mnemonic cues; in 1751, the Encyclopédie of Diderot and d'Alembert established the modern norm for the encyclopaedia as an alphabetized, multiauthor, multivolume and illustrated reference work; and at about the same time, Carl Linnaeus devised a precise set of rules for classification in nature. Wright pays special attention to the methods for classifying books between the late seventeenth and early twentieth centuries, which culminated in the development of multi-tiered, expandable hierarchies of standardized headings, such as Melvil Dewey's decimal classification in the late nineteenth century. He points out that libraries and librarians have long been at the forefront of information management techniques.

Finally, Wright considers twentieth-century attempts to form a universal collection of retrievable information, many of which are now forgotten, although their original ambitions are partially realized in the World Wide Web. Paul Otlet, for example, was a Belgian bibliographer who dreamed of guiding users not just to the right books, but to their contents. His Mundaneum (1910) eventually consisted of more than 12 million facts kept on index cards to which users could submit queries for a fee. The American engineer Vannevar Bush envisioned a machine called the 'memex', which would retrieve information to match a query from texts stored on microfilm. Although Bush's article 'As we may think' (Atlantic Monthly, 1945) is considered seminal today, Wright notes how little current information science

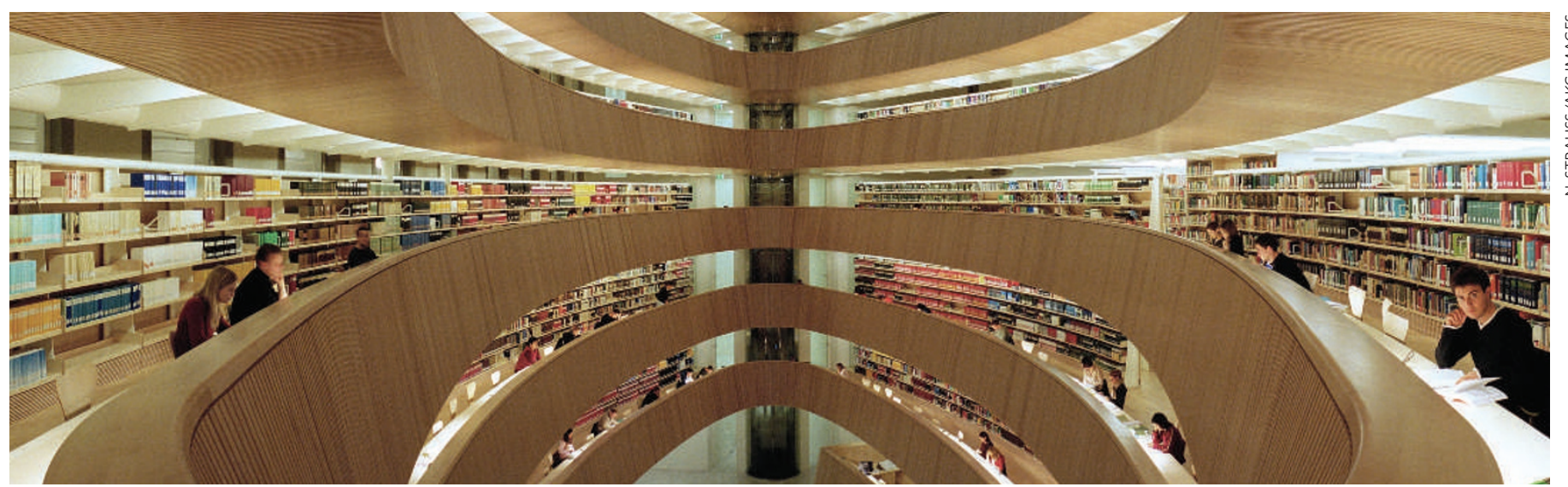

Many information management techniques were first developed in libraries, where hierarchical classification methods have existed for centuries. 
has heeded Bush's call for biological as well as mathematical models in computer science or his concerns about the influence of corporations on the growth of the field. Wright shows more generally how the Internet has developed beyond the control or the approval of its early contributors (such as Tim Berners-Lee or Ted Nelson, the conceptual father of hypertext).

The historical perspective of Glut is admirable: Wright neither assumes a linear progress nor makes unwarranted claims about the novelty or the indebtedness of current technologies to earlier ones. He doesn't try to predict what the lasting impacts of the Web will be, but notes that the Internet facilitates the formation of small, self-organized communities that have the potential to undermine large hierarchical structures. In this way, he suggests that human culture may no longer be moving unidirectionally as was once thought, towards coalescence into larger entities, but rather multidirectionally. Wright clearly values the growth of grassroots self-organization on the Web, but also acknowledges that bottom-up networks can benefit from some hierarchical structure.

One pay-off of attending to earlier ambitions for information control is to highlight some of the weaknesses of our current system. Wright notes, for example, that our search algorithms and the metadata they create are not transparent but are the work of software engineers operating within a world of commercial secrecy; and our weblinks that carry information about intellectual associations are evanescent and can disappear without leaving a trace. Using the analogy of print's arrival in the mid-fifteenth century, Wright warns of the potential for new technologies to seriously disrupt established structures. However, his interpretation that printing caused the Protestant Reformation is overly reductionist.

Wright's conclusion that "as Internet users continue to congregate in small groups, such behavior harkens back to our deepest rooted social instincts" is less convincing. This type of hasty sociobiological generalization argues from evidence selected to suit its purposes, without weighing counterevidence or other contributing factors. That humans have evolved a desire to communicate and form social groups does not strike me as the most helpful explanation for the complex choices we make among the many means of communication now at our disposal. Indeed, Wright shows throughout his book how the tools that were developed in different historical contexts to cope with information overload continue to shape our options and ambitions today.

This stimulating book offers much opportunity to reflect on the nature and long history of information management as a damper to the panic or the elation we may variously feel as we face ever greater scales of information overload.

Ann Blair is a professor of history at Harvard University, Cambridge, Massachusetts 02138, USA.

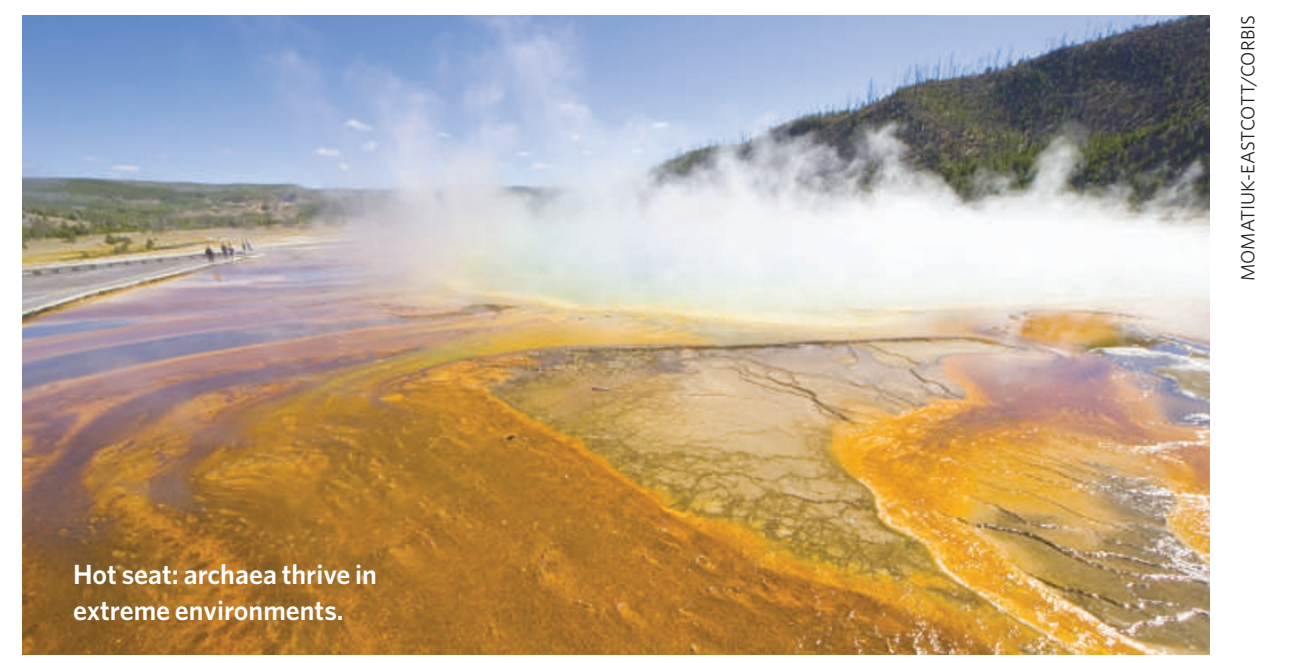

\section{Introducing the extremophiles}

\section{The Third Domain: The Untold Story of Archaea and the Future of Biotechnology by Tim Friend \\ Joseph Henry Press: 2007. 250 pp. \$27.95}

\section{Sean Nee}

Envy the achievement of Carl Woese, who announced his discovery of the third domain of life on Earth a mere 30 years ago. Marvel at the fact that most people are unaware of this three-domain understanding of biodiversity. Admire the journalist Tim Friend who resigned from the newspaper USA Today to write this superb book introducing the public to the third domain. Buy it and enjoy the personalities, the adventures, the drama and the science too, all presented in an admirable mix that is a terrific read.

Until recently, our view of life on Earth had changed little over centuries. There were animals, plants and a bunch of little things such as bacteria. One of the many quaint anachronisms of the University of Oxford is that it is still one of the few seats of learning to have separate departments of plant sciences and zoology, reflecting a view of life that is as outdated as snuff after dinner and bulldogs in bowler hats (don't ask). It is probably no coincidence that Oxford's most famous popular writer on biology, Richard Dawkins, notoriously gave only a single page to the third domain of life in his take on biodiversity, The Ancestor's Tale, apparently more interested in things like cabbages.

Here are the three domains. Bacteria: you know what they are but you probably have no idea how interesting they are - but that's another book. Eukaryotes: unlike bacteria, eukaryotic cells enclose their genetic material in an internal membrane and have lots of internal membrane-bound organelles. This domain includes multicellular plants and animals, but these are small beer compared with the enormous diversity of single-celled eukaryotes, most of which we know about only because they cause disease, such as giardia. The third domain, the subject of this book, is the archaea. Although they are single-celled and definitely not eukaryotes, they are not bacteria either. To see this point clearly, know that there are no archaea that cause disease. If anyone has a good idea why this is, please contact me at once. It is not that they are only found in strange places where we do not go - your mouth, for example, is teeming with them. Also, a particular antibiotic that works by disrupting the information-processing machinery in bacteria has no effect on eukaryotes or archaea. The current understanding is that we share the same information-processing genes as archaea.

It had long been conventional wisdom that the phylogeny - the family tree - of bacteria could not be constructed. Until recently, phylogenies had been based on morphology: we look quite like gorillas and chimps, less like gibbons, even less like howler monkeys, not at all like cabbages, and so on. These degrees of similarity reflect the length of our separation in evolutionary time. But morphology is useless for bacteria: they are blobs, squiggles or rods. That tells us nothing.

Soon after the invention of DNA-sequencing technologies, Carl Woese had the insight that comparing sequence similarities between bacteria might allow the construction of their phylogeny, and he got to work. He chose a particular gene that is essential in translating DNA into proteins and so must be found in all life forms - at least, as understood at the time. Having sequenced a segment of the gene in many bacterial species and found reasonably varying degrees of similarity, a colleague down the hall brought him some 'bacteria' with an unusual metabolism: methanogens get their energy by combining hydrogen and carbon dioxide, producing the potent greenhouse gas methane as an end product. These are responsible for swamp gas, for example, and about $50 \%$ of you reading this have them in your gut. This is one of the gases that allows you to do 